\title{
The Responsibility to Protect in a Changing World Order: Twenty Years since Its Inception Michael Ignatieff
}

I was a member of the International Commission on Intervention and State Sovereignty (ICISS), chaired by Gareth Evans and Mohamed Sahnoun, and The Responsibility to Protect, published in 2001. ${ }^{1}$ I still remember the excitement at the meeting in Delhi when Evans first circulated the idea, initiated by Francis Deng, of rethinking sovereignty not as a right but as a responsibility and of rethinking intervention not as a discretionary strategy of the powerful but as a responsibility restricted to protecting populations at the mercy of massacre or displacement within their own state. It was thrilling to be part of such an exercise in "norm entrepreneurship." As we finished drafting the report in 2001, we were hopeful that these ideas would be translated into norms, and then over time into international practice. If they were, we hoped we would have done our part in preventing a recurrence of the catastrophes that haunted the 1990s: Bosnia, Rwanda, and Kosovo.

Since its publication, The Responsibility to Protect has stimulated two decades of debate, argument, and controversy. Small wonder. It was the most penetrating and provocative reformulation of sovereignty since the drafting of the UN Charter in 1945. As Michael Doyle says, RtoP was intended to be both a "license"-an authorization of a variety of instruments, not just force-to protect populations and a "leash" against unilateral intervention by great powers. Some critics have feared the license is too permissive; others that the leash is either too long or too short. ${ }^{2}$

Michael Ignatieff is the director of Central European University, located in Vienna, Austria.

Ethics \& International Affairs, 35, no. 2 (2021), pp. 177-180.

(c) The Author(s), 2021. Published by Cambridge University Press on behalf of the Carnegie Council for Ethics in International Affairs. This is an Open Access article, distributed under the terms of the Creative Commons Attribution licence (https://creativecommons.org/licenses/by/4.o/), which permits unrestricted re-use, distribution, and reproduction in any medium, provided the original work is properly cited.

doi:10.1017/So892679421000228 
I am proud to have been one of the drafters of the report, but looking back now, the whole project belongs to a vanished era. We took the contingent realities of our time to be permanent features of the international landscape: American ascendancy; China on the rise but, like Russia, reluctantly acquiescent to American dominance, resulting therefore in a Security Council prepared to legitimize the leadership of the "indispensable" nation. How distant this all seems now.

At ICISS, though we never explicitly spelled them out, we took at least three assumptions for granted. We assumed that (1) there would be coalitions of the willing, under U.S. leadership, ready and able to intervene to protect civilians; (2) these coalitions would be able to secure Security Council legitimacy for their actions; and (3) there would be a human rights consensus in our domestic populations favoring interventions to protect faraway civilians from harm.

Within a week of the publication of the ICISS report, an apocalyptic event-the 9/11 attacks-began the tectonic shift away from the world in which these assumptions held true. The political climate resulting from the attacks allowed the Bush administration to drum up domestic support for the ill-fated $2003 \mathrm{U}$. S.-led invasion of Iraq. But the ensuing sectarian civil war and the rise of ISIS destroyed domestic support for military intervention. By 2011, with Libya, America could only be persuaded to "lead from behind," following Britain and France. Here, too, the consequences of the NATO-led intervention-civil war, economic collapse, insurgency through West Africa, and mass migration using a prostrate Libya as its departure point-solidified the conviction, among politicians and their publics alike, that protecting civilian populations was an enterprise fraught with hazardous and unmanageable consequences. By the time Syria's Bashar al-Assad launched a war against his own people, political support for intervention had vanished entirely from democratic publics. With Syria, Russia ranged its Security Council veto on the side of a murderous regime and made any UN-sanctioned protection operation impossible. With Myanmar, too, state-sponsored ethnic cleansing received a tacit green light from China, another Security Council member.

This is the world that no one in the ICISS team anticipated: the always-fragile support for military intervention now vanished; the Security Council so deadlocked that it cannot even agree on resolutions to combat a truly global threat such as the coronavirus pandemic; and an America reluctant about the entire gamut of its international obligations, beset by internal division and decay, and uncertain about whether to manage or confront an ascendant China. 
The mental universe from which ICISS sprang imagined that we were moving beyond a world of sovereign states toward an interdependent world, governed by international bodies, universal norms, and a global capitalism that would, eventually at least, include more and more people in its magic circle of prosperity. It is now hard to see this as the future toward which we are headed. We remain stubbornly and incorrigibly in the Westphalian world, in an international order of sovereign states, jealous of each other's prerogatives, protective of our borders, and united-to the degree that we agree on anything at all-in the defense of each of our sovereignties. This is sovereignty not as responsibility but as inviolability. No matter that globalization weakens the effective economic sovereignty of even powerful and capable states. No matter that a new predatory neoimperialism from China is weakening the sovereignty of less powerful and less capable states in Africa and Asia. Faced with the invasive forces of economic globalization and the emergence of new forms of neoimperialism, it is small wonder that embattled states, small, medium, and large, want to reinforce such legal protections of their sovereignty as remain.

The fact that we actually need more multilateral cooperation than ever in the face of our common problems-epidemics, climate change, terrorism, and cybersecurity-does not mean we will resume the march toward a strengthened multilateralism any time soon. Indeed, it is through their sovereign governments that nations have confronted each of these challenges. If there is multilateralism in our future, it will be through organizations like the European Union, which is painfully dependent on securing consensus among stubbornly sovereign actors.

So where does that leave responsibility to protect (RtoP)? Good ideas do not always die just because the times in which they were first articulated turn out to be too barren for them to sprout. They remain on the ground, seeds awaiting a time to germinate. Any historian can point to ideas-women's suffrage, the Lieber Code, the Nansen passport, Earth Day-that took decades before their time came and they returned to the fore again, their moral authority undiminished, their relevance and urgency suddenly clear to all. Let us just hope it does not take a catastrophe-a famine, a civil war, a violent outbreak of ethnic cleansing-to make politicians and citizens alike remember, once again, that sovereignty is not a license to kill but an obligation to protect.

With this in mind, 2021 provides an important opportunity to reflect on RtoP, while also considering its future. As part of that reflection, this roundtable brings together experts in the field to analyze the responsibility to protect at twenty in the 
context of the changing world order I have sketched out. First, Adrian Gallagher and Nicholas J. Wheeler's examination focuses on trust, distrust, and trustworthiness in relation to RtoP's so-called third pillar and the use of force. Drawing on the vast literature on trust from other domains, they argue that a key enabling (but not determining) condition of the use of force by the UN Security Council for humanitarian purposes is the trust that its members have in particular states that are willing to intervene to save endangered populations. Second, Christina G. Stefan analyzes RtoP through the lens of norm entrepreneurship, discussing not only the early years of ICISS but also its more recent efforts to champion the principle in today's transitional global order. She focuses in particular on the adaptability and mobilization efforts of non-Western norm entrepreneurs with regional ambitions, and discusses how these unexpected "champions" might increase the legitimacy of RtoP itself. Third, Luke Glanville and James Pattison highlight the challenge of multiple ongoing crises of protection and how states are required not simply to decide whether and how to protect but also where to protect. This involves considering which among several instances of mass atrocities states should prioritize when there is only a limited degree of resources and willingness in the international community to respond. Finally, Jennifer M. Welsh reflects on the mixed record of the UN Security Council in fulfilling its responsibility to protect, in light of the expectations and recommendations set out in our ICISS report. While on the one hand, Council members have acted in more expansive ways than perhaps foreseen by the commissioners, their paralysis and limited action in key instances of atrocity crimes underscores the cost of the failure to seriously consider or develop alternatives to the Council in order to strengthen our global architecture for protection.

\section{NOTES}

${ }^{1}$ International Commission on Intervention and State Sovereignty, The Responsibility to Protect (Ottawa: International Development Research Centre, December 2001).

2 Michael W. Doyle, “The Politics of Global Humanitarianism: The Responsibility to Protect before and after Libya," International Politics 53, no. 1 (2016), pp. 14-31.

\footnotetext{
Abstract: This introduction to the roundtable "The Responsibility to Protect in a Changing World Order: Twenty Years since Its Inception" argues that the geostrategic configuration that made the responsibility to protect (RtoP) possible has changed beyond recognition in the twenty years since its inception.
}

Keywords: intervention, sovereignty, Syria, Iraq, responsibility, responsibility to protect 